\title{
A 21. SZÁZAD KÉPI NYELVÉNEK TANÍTÁSA A BAUHAUS MAGYAR MESTEREINEK PEDAGÓGIAI ÖRÖKSÉGE NYOMÁN
}

\section{TEACHING THE VISUAL LANGUAGE OF THE $21^{\text {ST }}$ CENTURY BASED ON THE EDUCATIONAL HERITAGE OF HUNGARIAN BAUHAUS MASTERS}

\author{
Gaul Emil', Havasi Tamás², Nagy Imre', Sándor Zsuzsanna ${ }^{4}$ \\ PPhD, DLA, ny. egyetemi tanár, gaul@t-online.hu \\ ²múvésztanár, Nyíregyházi Egyetem Vizuális Kultúra Intézet, havasit@gmail.com \\ ${ }^{3}$ DLA, tanszékvezető egyetemi docens, Magyar Képzőmúvészeti Egyetem Tanárképző Tanszék, nagy.imre.mke@gmail.com \\ ${ }^{4}$ PhD, egyetemi docens, Eszterházy Károly Egyetem, sandor.zsuzsanna@uni-eszterhazy.hu
}

\begin{abstract}
ÖSSZEFOGLALÁS
A 20. századi művészeti nevelés a hazai közoktatásban még fel nem dolgozott öröksége, a Bauhaus magyar mestereinek pedagógiai elvei és gyakorlata alapján négy, a jelenleg érvényben lévő, 2012-es Nemzeti Alaptantervben meghatározott követelmények és tartalmak lefedésére alkalmas oktatási koncepciót dolgoztunk ki. Az iskolai kísérletek az MTA tantárgy-pedagógiai pályázata támogatásával a "Moholy-Nagy Vizuális Modulok - a 21. század képi nyelvének tanítása" című kutatási projekt keretében zajlanak 2016-2020 között, a vizuális kultúra (korábban rajz) tantárgy tanításának korszerúsítése érdekében.

A Vizuális kommunikáció, Vizuális média, Környezetkultúra és $A$ kortárs vizuális müvészet tanítása című tantervi modulok az elmúlt évtizedek hazai művészetpedagógiai innovációira és az Európai Vizuális Műveltség Keretrendszerre építenek. A modulprogramok egyenként vagy kombinálva, a NAT egyéb tartalmaival kiegészítve is használhatók. A moduláris tervezés lehetővé teszi, hogy a tanár a tanulók érdeklődése és saját tanári stílusa szerint alakítsa a tanítási-tanulási folyamatot, és így egy-egy témát hosszabb időtartamban, ezáltal elmélyülten is tanulmányozhassanak a tanulók. A kutatócsoport harmincnégy tagjának részvételével valamennyi modulhoz elkészültek a pedagógiai programok, az első tanéves tanítási-tanulási tervek és a tanítási tapasztalatokat is tartalmazó digitális kézikönyvek, amelyek mind megtekinthetők honlapunkon. Cikkünkben a négy modult ismertetjük röviden.
\end{abstract}

\section{ABSTRACT}

A new methodology for art education and curricular modules are being elaborated by the MTA-ELTE Visual Culture Research Group, based on educational theories and practices of the Hungarian masters of the Bauhaus art and design college. This important educational legacy has not been utilised so far in Hungarian public education. The curriculum development to be carried out between 2016 and 2020 is entitled "Moholy-Nagy Visual Modules - teaching the visual language of the $27^{\text {st }}$ century" to modernise the contents and methods of "Visual culture", the discipline for art education in Hungary 
The curricular modules entitled Visual communication, Visual media, Design education, and Teaching contemporary art, are based on research and innovation in Hungarian art education and also on the Common European Framework of Reference for Visual Literacy developed by the European Visual Literacy Network. The modules can be used alone, or in combination with other contents of the National Core Curriculum. The modular structure offers a flexible planning approach, adaptable to the interests of students and teaching strategies of the art educator. Meanwhile it encourages longer periods of study focusing on one thematic area which will hopefully result in deep learning. With the contribution of the 34 members of the research group, pedagogical programmes and teaching plans have been published for all modules, supplemented by reports on the first piloting period. Supplemented by detailed and illustrated lesson plans, they are available on the project web site and may serve as an inspiration for teachers of art. This paper provides an overview of the four Moholy-Nagy Visual Modules.

Kulcsszavak: művészetpedagógia, tantárgy-pedagógia, művészetalapú kutatás, képességfejlődés

Keywords: art education, curriculum development, arts-based research, skills assessment

\section{A VIZUÁLIS KOMMUNIKÁCIÓ TANIITÁSÁNAK SZAKMÓDSZERTANI KUTATÁSA}

A vizuális kommunikáció modul koncepciója több vonatkozásban rokon a Bauhaus német mủvészeti föiskola eszmerendszerével és egyik kiemelkedő képviselője, Moholy-Nagy László művészetelméleti gondolataival. A Bauhaus egyik legfontosabb célja volt, hogy a müvészetek egymás közötti és társadalmi elszigeteltségét megszüntesse. Moholy-Nagy így ír erről: „Az ipari korszakban a müvészet és a nem-müvészet, a kézmúvesség és a gépi technológia közötti megkülönböztetés elveszti abszolút jellegét.” (Moholy-Nagy, 1944, idézi Passuth, 1982, 345.) Felfogása szerint a modern kor - mivel kollektív gondolkodásra, cselekvésre és kollektív formateremtésre irányul - az alkotótevékenységben a megformálás objektív törvényszerüségeinek a kialakítását követeli meg. A müalkotás a társadalom minden rétegének szól: „Nekünk nem »összmúvészetre« van szükségünk, amely elkülönül a mellette tovaáramló élettől, hanem az élet valamennyi mozzanatából felépülő szintézisre, amely végül összmüvé (életté) válik, amelyik egyúttal minden elszigeteltséget megszüntet, és amelyben minden individuális teljesítmény biológiai szükségszerüségből fakad, és egyetemes szükségszerüségbe torkollik" (Moholy-Nagy, 1978, 15.). Kommunikációs vonatkozásban Moholy-Nagy müvészetelméletéből tehát aktív-dinamikus, társadalmi összefüggésekre figyelő (művészeti) kommunikáció képe bontakozik ki. Moholy-Nagy szellemében a „Moholy-Nagy Vizuális Modulok - a 21. század képi nyelvének 
tanítása" címủ kutatásban ${ }^{1}$ a vizuális kommunikáció modul pedagógiai koncepciójának legfontosabb jellemzőit röviden a következők szerint foglalhatjuk össze:

a) A vizuális kommunikáció értelmezésében a vizuális világ egészére, a képi, tárgyi és környezeti alkotásfajták mindegyikére értjük, és társadalmi problémák feldolgozásával, a participációs kommunikáció (Nyíri, 2001) felfogással hozzuk összefüggésbe.

b) A pedagógus és a tanítvány viszonyában a mentori szerep a meghatározó, a tanítványok és a célokra szerveződött tanulói csoportok egyedi tanulási utakat járnak be. A tanár szervező, segítő és bátorító mentorrá válik, a tanuló pedig a korábbinál sokkal nagyobb választási és döntési pozícióhoz jut, amelyhez nagyfokú önállóság társul.

c) A koncepció részeként megfogalmazott témakörök karakterében a projektmódszer a legfontosabb, ahol társadalmi vonatkozásban hasznos, müvészi vagy nem müvészi vizuális alkotások egyenrangú alkalmazásával zajlik a feladatok feldolgozása.

d) A vizuális kommunikációs projektekben a kommunikatív aspektus mindig valamilyen élethelyzetre irányul, az élet valamely problémájára keres megoldást. A tanulók az együttmüködés során kerülnek kommunikatív aspektusba osztálytársaikkal, a tanárukkal és tágabb környezetükkel, miközben sokféle szocializációs és kommunikációs helyzetet élnek át.

Mindezek szellemében kiemelt célunk a tantárgyi feladatokban megjelenített, illetve azokon keresztül bemutatott egyéni, társadalmi, környezeti problémák iránti érdeklődés felkeltése. Ilyen módon a tanulókban erősítjük a kezdeményezőkészséget, támogatjuk az alkotó-cselekvő magatartást, az együttmüködési képességet és empátiát.

\section{A VIZUÁLIS MÉDIA KOMMUNIKÁCIÓ SZAKMÓDSZERTANI KUTATÁSA}

„A film kultúrája a néző kultúrájával nőtt. A történelemben egyetlen hasonló folyamat sem állapítható meg az egyetemes, minden népet és földrészt magában foglaló kontrollt illetőleg valamely müfaj és annak fejlődésével kapcsolatban, mint a film esetében. Minden ember életében a számszerüleg nagy mozilátogatás miatt a legprimitívebb mozilátogató is képes a film felett kritikát gyakorolni s a teremtői elemek minden ellanyhulását regisztrálni. Mely irányból jöjjön azonban a teljesítmény, ha a mủvészt a teremtői folyamatból kikapcsolták?” (Moholy-Nagy, 1934, 153.) Kutatásunk névadója a fenti idézetben olyan, a mai technikai fejlett-

\footnotetext{
${ }^{1}$ A „Moholy-Nagy Vizuális Modulok - a 21. század képi nyelvének tanítása” című projekt honlapja: URL1.
} 
ség révén kiszélesedő folyamatot vázol, amely napjainkban is aktuális. A film, a mozgókép, a fotó, általában a technikai médiumok, a digitalizáció során egyre demokratikusabbá, mindenki számára elérhetővé, használhatóvá válnak, „a néző kultúrájával nőnek". A másik jelenség, amelyre Moholy-Nagy felhívja a figyelmet: az értő alkotó, a művész, nélkülözhetetlen a teremtő folyamatban.

Az „új képi világ” a fiatalok életét, társas kapcsolataikat minden elemében átszövi (Nyíri, 2001, o. n.). Az általuk alkotott, fogyasztott, preferált digitális képek mennyisége megnövekedett, tematikai jellegzetességei és a fiatalok „használati” szokásaiban bekövetkező változások is indokolják a médianevelés és a vizuális nevelés komplex átgondolását. A mai fiatalok nem egyszerűen passzív médiafogyasztók, hanem a digitális technológiákat naponta használó, aktív médiaalkotók is. A nyitott és értő befogadásra nevelés mellett az alkotást is segítenünk kell, hogy a befogadói és az alkotói képességeket is integráló digitális kompetenciát alakíthassunk ki (Kárpáti-Gaul, 2011).

Miközben követjük a változó képiséget, technikai fejlődést és használati trendeket, szilárd müvészetpedagógiai fókuszt is keresünk. Ezek az ,állandónak” tekinthető tematikák a programban átszövik a vizuális kultúra óratevékenységeit. Ilyen téma, illetve tevékenység például a képolvasás, látványolvasás vagy a kép és a szöveg változatos kapcsolódási lehetőségei. A nézőpont vizuális, illetve tágabb értelmezése vagy a montázs képi és auditív értelmezése, különösen fontos terület. A mozgás és az idő ábrázolásának vizsgálata a mozgóképes gondolkodást alapozza meg. A képi, zenei és irodalmi alkotásokban egyaránt előforduló kifejezőeszközök (mint például a ritmus és a kommunikációs jelrendszerek) összefüggéseit tárgyalják, míg a szituációs játékokon keresztül az üzenet kontextusait veszik számba.

A médianevelés legfontosabb feladatai közzé tartozik a média változatos nyelvezetének, a szövegértési képességnek elsajátitása, de technikai, müfaji ismereteket is közvetiteni kell. A média közönsége az a fogyasztói csoport, amelynek szokásaival, igényeivel kell megtanulnunk azonosulni, akár felhasználók, akár alkotók vagyunk. A célközönség számára a különbözö médiumok produktumai reprezentálnak valamilyen eszmét, értéket stb. A közösségi média különbözö platformjai az önreprezentáció lehetőségét biztosítják. Korosztálytól függően és mértékben a technikai médiumok történetével, a médiaelmélet, manipulációelméletek, médiafilozófia és médiaesztétika témakörei régóta igényelt és mindeddig hiányzó témák voltak a vizuális kultúra órán (Bodóczky, 1999, 6-28.).

A „Moholy-Nagy Vizuális Modulok - a 21. század képi nyelvének tanítása” „Vizuális média” moduljában, a felvázolt gondolatmenetet követve, az egymásra épülő 9-11. évfolyamokon különböző vizuális közlésformák és médiumok kapnak kitüntetett figyelmet. Elöször a kép, majd a szöveg, a kép és a szöveg kapcsolata, majd ezek a kifejezőeszközök a közösségi médiumok kontextusában, a mozgókép, a médiamủvészet különböző formái és végül a multimédia, valamint a virtualitás témakörei épülnek egymásra a tanítás során. 


\section{A TÁRGY-ÉS KÖRNYEZETKULTÚRA TANITTÁSÁNAK SZAKMÓDSZERTANI KUTATÁSA}

Moholy-Nagy László a Bauhaus tanáraként egyik megteremtője volt a kor igényeire reflektáló új szakembernek, a designernek. A csővázas bútorok tervezőjeként is világhírre tett szert, csakúgy, mint Breuer Marcell, ám a tervezői munkásságánál számunkra nagyobb jelentősége van pedagógiai életművének, amelyet a Bauhausban végzett tanári tevékenysége során írt müvészetpedagógiai müveiből ismerhetünk meg. Az anyagtól az épitészetig címü 1929-es könyvében (Moholy-Nagy, 1968) fekteti le máig érvényes nevelési alapvetését: a teljes ember neveléséről (szemben a „szelet emberrel”), a mindenkiben rejlö tehetség kibontakoztatásáról. Szerinte a technika nem cél, hanem felhasználandó eszköz, és nem a megtervezett tárgy, hanem az azt használó ember a fontos. A Bauhaus ethosza és nevelési elvei az építészetben és terméktervezésben még ma is, kilencven év múltán, világszerte elterjedtek.

A „Moholy-Nagy Vizuális Modulok - a 21. század képi nyelvének tanítása” címü kutatási programban ezúttal arra teszünk kísérletet, hogy a közoktatás színterén tegyük a tanárok módszertani kultúrájának részévé pedagógiai elképzeléseit, és az általános müveltségbe építsük a környezetkultúráról vallott nézeteit. Különösen fontosak ezek egy olyan korban, amikor az épített és tárgyi környezet minőségének, benne formai karakterének jelentősége felértékelődik.

A tárgy- és környezetkultúra tanításának egyik célja, hogy elmélyítse az anyagi kultúra e speciális területének megismerését, felhívja a figyelmet a benne lakozó információkra és szépségekre, és ez által legalább ismerőssé, élhetővé és, ha lehet, akkor otthonossá tegye az ember alkotta környezetet. A környezetkultúra tágabb értelmezésében benne foglaltatik annak létrehozása: maga a tárgy, valamint annak használata, és mindaz a tudás, ami az alkotáshoz és a környezet szakszerü használatához kell. A környezet alakításában központi helyet foglal el a lehetőleg szeretettel végzett, örömteli emberi munka, amit két szakaszra bontunk: a tervezésre és a tervek megvalósítására.

Egy épület vagy egy ipari tárgy tervezése és megvalósítása is több szakterület együttműködésével jön létre, így a környezetkultúra tanítása és tanulása magától értetődően közösségi tevékenység, és ekként fejleszti a kooperációs készséget és az empátiát (Kagan, 2001). A témakör szerepmodellje a tervező: mérnök, designer vagy építész, aki a rajz tantárgy hagyományos föszereplöje, a festőmüvész mellett lép színre, és képviseli ezt a mindennapi életünk szempontjából oly fontos területet (Kárpáti, 2015).

A fejlesztési célok között szerepel a vizuális kultúra tantárgy középpontjában lévő alkotóképesség és kritikai érzék kibontakoztatása és az érdeklődés felkeltése azon problémák iránt, amelyeknek a megoldása egy tárgy. A problémamegoldás gyakorlati válfaja ez, amelyet minél életszerübb környezetben gyakoroltatunk. Különös és sajátos szerepe van a tervszerü gondolkodás fejlesztésében, az opera- 
cionális - eljárás jellegü és nem tudatosított - tudás kialakításában (Nagy, 1998), valamint a tapasztalati megismerésben. A fejlesztés módszereként a feladatok mellett nagy szerepet kaphatnak a projektek, amelyekben a tanár által ajánlott élethelyzetben kell felismerni a problémát, majd megoldást találni rá (Gaul, 2011).

\section{JOHANNES ITTEN ÉS A KORTÁRS MŪVÉSZET TANITTÁSA}

A Bauhaus művészeti főiskolán a megismerés kiindulópontja a „nyers”, „rendezetlen” anyag volt. Ebből „hozták létre a világot”, „manuális szellemi tevékenység” során (Mezei, 1975). Az iskola talán legnagyobb hatású módszertani újítását, az Alapkurzust, vagyis az egyes mủvészeti ágak művelésére előkészítő tanfolyamot Johannes Itten svájci képzőmüvész-pedagógus szervezte meg és vezette 1919-től 1923-ig. Koncepciójában az első célt így fogalmazta meg: „Felszabadítani a tanulók alkotóerejét és ezáltal művészi adottságaikat úgy, hogy önálló élmények és felismerések vezessék őket az igazi munkához" (Mezei, 1975).

Elgondolása szerint a tevékenységnek felszabadító hatása van, a tevékenység során több érzékelési terület aktív, és ez megmutatkozik a készségek fejlödésében, a tanulók személyes karakterének kibontakozásában. A közvetlen átélés, a megismerés és a tudás szoros kapcsolatára alapozta tevékenységét, az ember pszichikumát és fizikumát koordinált egységként ragadta meg. Szélső helyzeteket modellezett ellentétes fogalompárjaival, ezzel az állapotok között zajló, feszültségkeltő kölcsönhatásokra irányította a figyelmet.

Koncepciójában az elfogulatlan, feltáró megközelítést, a konstruáló erőt, a szerveződő struktúrát helyezte előtérbe, és háttérbe szorította a funkció meghatározóit. Itten megközelítése nem áll távol Martin Heideggerétől, a müalkotás eredetét vizsgáló, több mint egy évtizeddel későbbi előadásaiétól, utóbbit pedig pszichológiai vizsgálatok és az agyi müködés funkcionális aszimmetriájának vizsgálatai is alátámasztották (Heidegger, 1988; Taylor, 1983; Hámori, 1985).

A kortárs müvészet közvetítéséhez más megközelítésre van szükség, mint a régebbi korok mủvészetének tanításához, ahol egymás után újabb és újabb időrétegeket építünk fel, hogy történetileg hiteles építményt alkothassunk. A kortárs müvészet megközelítésében a kezdeményező attitüdnek van kiemelkedő jelentősége. Ahhoz, hogy valamilyen viszonyba kerülhessünk kortárs alkotásokkal, nekünk, nézőknek kell az első lépést megtennünk. Ha fiatalokat szeretnénk bevinni ebbe a világba, gondolkodásuk és érzelmi viszonyulásuk spontán megnyilvánulásait kell kiindulópontnak tekintenünk, ezáltal ők kerülhetnek a művel való kapcsolatuk középpontjába. Ez olyan pozíció, amely kedvez a szabad interpretációnak, és közvetlenebb viszonyt teremt a világ jelenségeivel. Képletesen és konkrét értelemben is mühelyhelyzet alakulhat így ki. Egymástól távol eső elemek társulhatnak egymáshoz, feszültségük, dinamikájuk feltáró és alkotó folyamatokat kezd el táplálni. 
A műhelymunka során több személyes interpretáció találkozik, ennek révén az első személyes kiindulópontok átszerveződhetnek, bekapcsolódhatnak egy többelemü, nagyobb egységbe. A kortárs művek elsősorban környezetként vannak jelen. A velük való foglalkozás során parafrázisok, aktualizált új variációk keletkeznek. Több kortárs alkotás kapcsolódhat egymáshoz, és interpretációjuk által új, sajátos müvészeti közeg szerveződhet. Az érzékletes képi, tárgyi és az elvont fogalmi megközelítés összekapcsolódhat. Ebben a nyitott müértelmezési helyzetben előre nem jósolható meg, hogy mi lesz a végső állapot - a folyamatoké a föszerep. A mütörténeti elemző folyamatot a kereső, kutató attitüd határozza meg. Itt is a jelen idő a kiindulópont, innen elindulva tárulnak fel „régebben volt jelenek", ezzel az aktuális jelen köre kitágul. A kör nemcsak a múlt felé terjed ki, hanem a jelenben már benne rejlő jövő irányába is.

\section{KÖSZÖNETNYILVÁNITT́S}

A tanulmányban szereplő kutatások az MTA-ELTE Vizuális kultúra szakmódszertani kutatócsoport, „Moholy-Nagy Vizuális Modulok - a 21. század képi nyelvének tanítása, 2016-2020" projekthez kapcsolódnak. A kutatásokat a Magyar Tudományos Akadémia Tantárgy-pedagógiai Kutatási Programja támogatta.

\section{IRODALOM}

Bodóczky I. (1999): A médianevelés szerepe és lehetőségei a közoktatásban. In: Rézművesné Nagy I. (szerk.) (1999): Médianevelés a közoktatásban. (Segédanyag a Mozgóképkultúra és médiaismeret tanításához) Miskolc: BAZ Megyei Pedagógiai Intézet, 6-28.

Bodóczky I. (2002): Vizuális müvészeti projekt az oktatásban. (MIE Tanárképző Tanszék módszertani füzetek) Budapest

Flusser, V.: Képeink. In: Peternák Miklós (szerk.): Médiatörténeti szöveggyüjtemény I. Budapest: Magyar Képzőmüvészeti Egyetem, www.intermedia.c3.hu/mszovgyl/flusser2.htm

Gaul E. (2011): A tárgy-és környezetkultúra és tantárgy-pedagógiája. Nyíregyháza: Nyíregyházi Főiskola, http://repetha.detek.unideb.hu/media/documents/online_a_trgy-_s_krnyezetkultra_ copy.pdf

Hámori J. (1985): Nem tudja a jobb kéz, mit csinál a bal. Budapest: Kozmosz Könyvek

Heidegger, M. (1988): A müalkotás eredete. (ford. Bacsó Béla) Budapest: Európa Könyvkiadó

Kagan, S. (2001): Kooperatív tanulás. (ford. Galambos Rita) Budapest: Önkonet Kft. http://kemeny-eger.sulinet.hu/public/doks/kooperativ_tanulas.pdf

Kárpáti A. (2015): Vizuális nevelési modellek. In: Bodnár G. - Szentgyörgyi R. (szerk.): Szakpedagógiai körkép III. Müvészetpedagógiai tanulmányok. Budapest: ELTE, 149-168. http:// metodika.btk.elte.hu/file/TAMOP_BTK_BMK_4.pdf (utolsó megtekintés: 2017. 10. 23.)

Kárpáti A. - Gaul E. (2011): A vizuális képességrendszer: tartalom, fejlődés, értékelés. In: Csapó B. - Zsolnai A. (szerk.): Kognitív és affektív fejlödési folyamatok diagnosztikus értékelésének 
lehetöségei az iskola kezdő szakaszában. Budapest: Nemzeti Tankönyvkiadó, 41-82. http:// edia.hu/sites/default/files/books/Kognitiv_es_affektiv_diagnosztikus.pdf

Lajta Edit (szerk.) (1973): Müvészeti kislexikon. Budapest: Akadémiai Kiadó

Mezei O. (szerk.) (1975): A Bauhaus. Válogatás a mozgalom dokumentumaiból. Budapest: Gondolat Kiadó

Moholy-Nagy L. (1934): Nyílt levél a filmről. In: Mozgóképkultúra és médiaismeret szöveggyüjtemény. http://mek.oszk.hu/00100/00125/00125.rtf (utolsó megtekintés: 2017. 10. 23.)

Moholy-Nagy L. (1944): Industrial Design. In: Zucker, P. (ed.): New Architecture and City Planning: A Symposium. New York: Philosophical Library, 675-687. In: Passuth K. (1982): Moholy-Nagy László. Budapest: Corvina Kiadó

Moholy-Nagy L. (1968): Az anyagtól az épitészetig. Budapest: Corvina Kiadó (első német nyelvű kiadás: 1929)

Moholy-Nagy László (1978): Festészet, fényképészet, film. (ford. Mándy S.) Budapest: Corvina Kiadó

Nagy József (1998): A kognitív képességek rendszere és fejlődése. Iskolakultúra, 10, 3-21. http:// epa.oszk.hu/00000/00011/00020/pdf/9810.pdf

Nyíri Kristóf (2001): Az írásbeliségről és néhány médiumról. In: Béres I. - Horányi Ö. (szerk.): Társadalmi kommunikáció. Budapest: Osiris Kiadó

Passuth K. (1982): Moholy-Nagy László. Budapest: Corvina Kiadó

Taylor, I. A. (1983): Az alkotó folyamat természete. (ford. V. Binét Ágnes et al.) In: Halász László (szerk.): Müvészetpszichológia. Budapest: Gondolat Kiadó, 135-149.

Vizuális Kultúra kerettanterv. Oktatáskutató és Fejlesztő Intézet, Budapest. http://kerettanterv.ofi. hu/02_melleklet_5-8/index_alt_isk_felso.html (utolsó megtekintés: 2017. 10. 23.)

URL1: http://vizualiskultura.elte.hu 